\title{
Papers
}

\section{Pension funds and the evolving market for (ultra-)long government bonds}

Received (in revised form): 7th September, 2007

\section{Hans J. Blommestein}

is Head of the Capital Market and Public Debt Management Programmes at the OECD in Paris. Since 2004 he has also been the PwC Professor of Finance at Tilburg University, the Netherlands. He is currently serving on the editorial boards of various publications and is a member of the Governance Board of the OECD-Italian Public Debt Management Network and the OECD-led Emerging Markets Network (EmNet).

\begin{abstract}
The demand for long-dated bonds has increased, driven by stricter asset-liability matching regulations governing pension funds, new international accounting standards, as well as new risk-based regulations for insurance companies. Projections of rapidly ageing and longer-living populations in most OECD countries indicate that the demand for ultra-long paper is poised to grow further. Governments in several OECD countries have responded to that demand by starting or re-introducing the issuance of very long (20-30 years) and ultra-long (30 years and longer) bonds, provided that the issuance of those bonds is consistent with the cost-risk objectives of cost minimisation subject to a preferred level of risk. An important consideration for issuers is that pension funds and insurance companies are to some degree buy-and-hold investors. This may lead to illiquid markets in long-dated paper when the ongoing supply of (ultra-)long government bonds remains below a certain critical level, resulting in higher government borrowing costs than paper issued in liquid markets. Changes in regulatory standards and the adoption of new international reporting standards have increased the focus on liability-driven investing by pension funds. Although there is no useful (reliable) mechanical rule to determine - on the basis of a given amount of liabilities - the extent to which assets will be invested in (ultra-)long bonds, it is likely that there will be some re-allocation of the assets of many pension funds and insurance companies towards (ultra-)long bonds. Views, however, differ as to the pace and magnitude of such a re-allocation. Timing, however, remains a problem for many pension funds because of today's low interest rate situation, the ongoing financial turmoil and associated liquidity and risk-pricing problems. Against this backdrop many observers expect a gradual increase in the average duration of bond holdings because large-scale moves are expensive in the present low interest rate but highly uncertain environment.

Pensions (2007) 12, 175-184. doi:10.1057/palgrave.pm.5950059
\end{abstract}

Keywords: ultra-long bonds, issuance criteria of governments, ALM, liability-driven investing, long-term investing by pension funds

\section{Introduction and overview}

In several countries, pension funds and insurance companies are important investors in long-dated bonds. The demand for long-dated bonds has increased, driven by stricter asset-liability

Correspondence: Hans J. Blommestein, 2 Rue Andre-Pascal, 75016,

Paris, France.

Tel: +33 14524 7990;

E-mail: Hans.BLOMMESTEIN@oecd.org matching regulations governing pension funds in some countries, as well as new risk-based regulations for insurance companies. Likewise, new international accounting standards reinforce the need for pension funds to match assets and long-term liabilities. Projections of rapidly ageing and longer-living populations in most OECD countries indicate that the demand for ultra-long paper is poised to grow further. 
Governments in several OECD countries have responded to that demand by starting or re-introducing the issuance of very long (20-30 years) and ultra-long (30 years and longer) bonds, provided that the issuance of those bonds is consistent with cost-risk objectives of cost minimisation subject to a preferred level of risk. Consequently, there has been an increase in the supply of (ultra-)long bonds as a percentage of total bonds outstanding in many markets. The development of a liquid market in these bonds, ${ }^{1}$ however, requires sustained issuance by governments.

Although pension funds and insurance companies are important investors in long-dated paper, a significant part of demand also comes from relative value-driven accounts, such as asset managers, banks, and hedge funds. The degree to which pension funds and insurance companies dominate the market for (ultra-)long-dated bonds depends partly on the system of retirement savings, in particular the degree of pre-funding, the design of pension systems (defined-benefit versus definedcontribution, and the degree of indexation), the maturity of pension funds, and the role of insurance companies in the market for retirement products.

The long-term nature of the liability structures of pension funds and insurance companies is an important determinant of their investment strategies. Changes in regulatory standards and the adoption of new international reporting standards have increased the focus on liability-driven investing by pension funds. This is leading to a re-allocation of the assets of many pension funds and insurance companies toward (ultra-)long bonds. Views, however, differ as to the pace and magnitude of such a re-allocation.

Similarly, there is no useful (reliable) mechanical rule to determine, on the basis of a given amount of liabilities, the extent to which assets will be invested in (ultra-)long bonds. A first reason is that pension funds adopt very different mixes of alpha and beta strategies. Some pension funds argue that a significant degree of mismatching is warranted, so as to generate higher returns. A second consideration is the influence of the maturity of pension funds on the structure of liabilities. A third reason is that many funds use derivatives to match their liabilities, with some arguing that liability- matching swaps are to be preferred over cash bonds since swaps require very little capital to hedge the interest rate risk in the liabilities.

Pension funds and insurance companies are to an important degree buy-and-hold investors. This may lead to illiquid markets in long-dated paper when the ongoing supply of (ultra-)long government bonds remains below a certain critical level, resulting in higher government borrowing costs than paper issued in liquid markets.

Timing remains a problem for many pension funds because of today's low interest rate situation, the ongoing financial turmoil and associated liquidity and risk-pricing problems. Some analysts advocate matching and disregard the issue of timing. There is, however, still an element of timing in the sense that expected (further) rises in interest rates are likely to hold back large-scale moves. As a result, many observers expect a gradual increase in the average duration of bond holdings because large-scale moves are expensive in the present low interest rate but highly uncertain environment.

\section{Supply of long bonds: Recent issues of long-dated instruments by OECD governments ${ }^{2}$}

The United States, the United Kingdom, France, and Germany are among the OECD governments that have issued (ultra-)long bonds in recent years. The US Treasury announced in August 2005 that the sales of 30-year debt would be resumed in the first half of 2006, after suspending sales in October 2001.

In February 2005, the French government was the first country to issue successfully a 50-year nominal bond. Initially, the Agence France Trésor planned to issue EUR 3-5bn with a coupon of 4 per cent. More than EUR 19.5bn was bid, so the deal size was increased to EUR 6bn. The yield was 3 basis points above the benchmark 30-year bond.

On 26th May, 2005, the UK government re-introduced, after a break of more than 40 years, a 50-year gilt. In mid-July 2005, the United Kingdom Debt Management Office (UKDMO) organised a second sale. This bond was also sold via auction. In September 2005, UKDMO issued the world's first 50-year inflation-linked bond. This 50-year linker was sold through a syndicate of banks. There was 
robust demand, largely from 'real money' accounts. Since the offer drew bids totalling GBP $2 \mathrm{bn}$, the initial offer size of GBP $1 \mathrm{bn}$ was increased to GBP $1.25 \mathrm{bn}$. Moreover, the bond offered a real yield of only 1.112 per cent, the lowest ever on an inflationlinked bond, and priced 19 basis points below the 30-year inflation linker.

The issuance volume for 30-year bonds by the German government was increased in 2006 by EUR $1 \mathrm{bn}$ to EUR $12 \mathrm{bn}$ in response to changes in the structure of demand. On 19th April, 2005, the Dutch government re-entered the 30-year bond market. Apart from a lower coupon, this bond has the same characteristics as the 30-year bond introduced in 1993 (a 7.5 per cent coupon, with redemption in 2023). The offer drew bids totalling EUR 17bn, with the spread set at 4 basis points over German bunds. Allocations worth EUR 5.2bn were made.

Japan announced in December 2006 its intention to issue ultra-long-dated bonds in response to the demand of international investors. The first such issuance is expected later this year.

\section{Size and characteristics of markets for long-dated bonds}

Figures 1-3 provide a summary of the development in the markets for very long (20-30 years) and ultra-long (30 years and longer) nominal bonds in the period from 1996 to 2005 . The figures indicate that there has been an increase in long-dated instruments as a percentage of total bonds outstanding in most (but not all) markets. ${ }^{3}$

The increase in (ultra-)long bonds is also reflected by the increase in the average term to maturity, as shown in Figure 4.

\section{Motives of governments in issuing (ultra-)long bonds}

The issuance of government securities is targeted at the primary strategic objective of minimising borrowing (and management) costs of the government over the long term, subject to an acceptable level of risk. An indirect objective is to support efficient domestic government securities markets. The latter objective is 'derived', as it can be seen as part of the primary objective of the minimisation of borrowing costs.

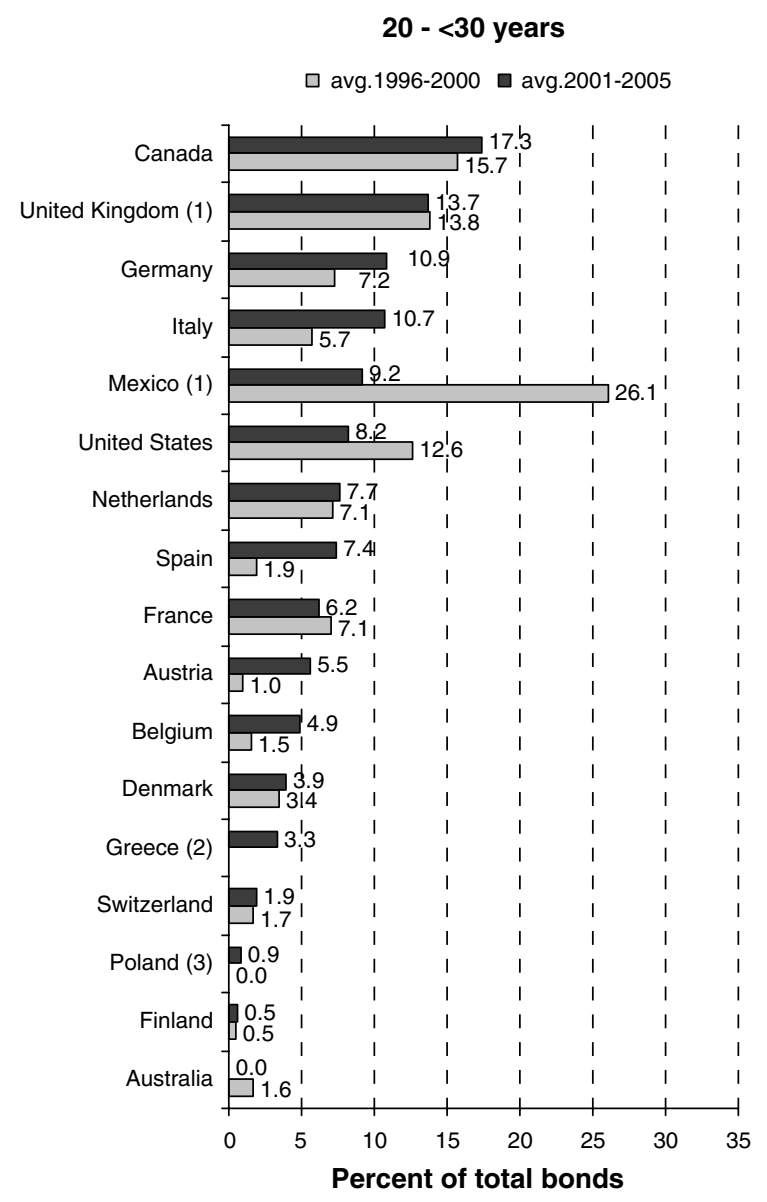

Figure 1: Government bonds outstanding, 20-30 years, averages. Government bonds outstanding by residual maturity, in percent of total bonds outstanding

Note: Countries are shown in order of recent averages. Total bonds are from OECD Central Government Debt Statistics (country tables item 1.2), except for Canada (where the data include only domestic currency securities), Japan, Korea, the Slovak Republic, the United Kingdom (where the data are in nominal terms), and Israel. Source: Replies to the OECD Working Party on Debt Management questionnaire on longterm bonds, OECD Central Government Debt Statistics, and OECD Secretariat calculations.

(1) Average for 1996-2000 is 1999-2000 only. (2) Average is 2002-2005 only. (3) Questionnaire data (nominator) cover only securities issued in national currency, while OECD Central Government Debt Statistics data (denominator) cover all bonds, regardless of the currency of issuance.

The issuance of (ultra-)long bonds is governed by this strategic framework. Several issuers have, therefore, indicated that the recent issuance of ultralong bonds is not motivated by opportunistic or ad hoc reasons but that these bonds are a new pillar of strategic longer-term borrowing programmes. Political or opportunistic pressures on issuers to weaken or undermine this longer-term perspective 
$30-<50$ years

口 avg.1996-2000 — avg.2001-2005

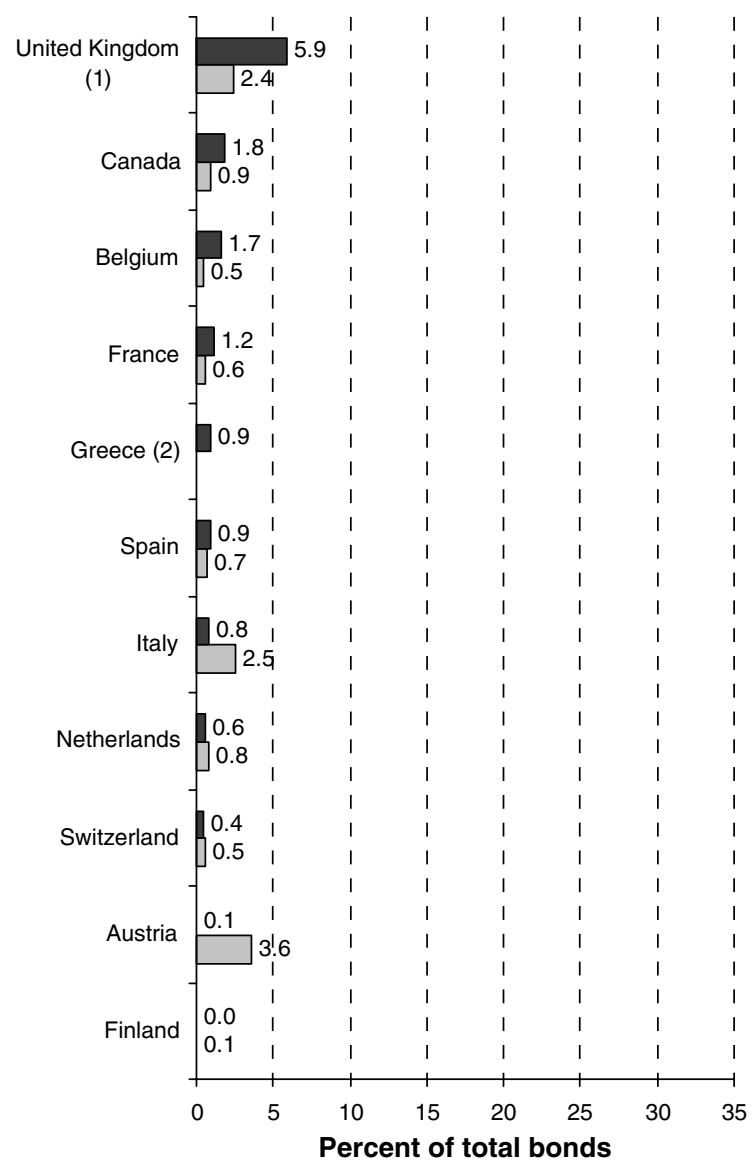

Figure 2: Government bonds outstanding, 30-50 years, averages. Government bonds outstanding by residual maturity, in percent of total bonds outstanding Note: Countries are shown in order of recent averages. Total bonds are from OECD Central Government Debt Statistics (country tables item 1.2), except for Canada (where the data include only domestic currency securities) and the United Kingdom (where the data are in nominal terms). Source: Replies to the OECD Working Party on Debt Management questionnaire on long-term bonds, OECD Central Government Debt Statistics, and OECD Secretariat calculations.

(1) Average for $1996-2000$ is $1999-2000$ only. (2) Average is 2002-2005 only.

(eg by widening or blurring the aforementioned primary strategic objective) are likely to be counterproductive. Deviating from this longer-term perspective would increase medium-term borrowing costs, while it would also endanger the regular issuance of ultra-long bonds. As noted, the development of a liquid market in long bonds requires sustained issuance by governments.
50 years and more

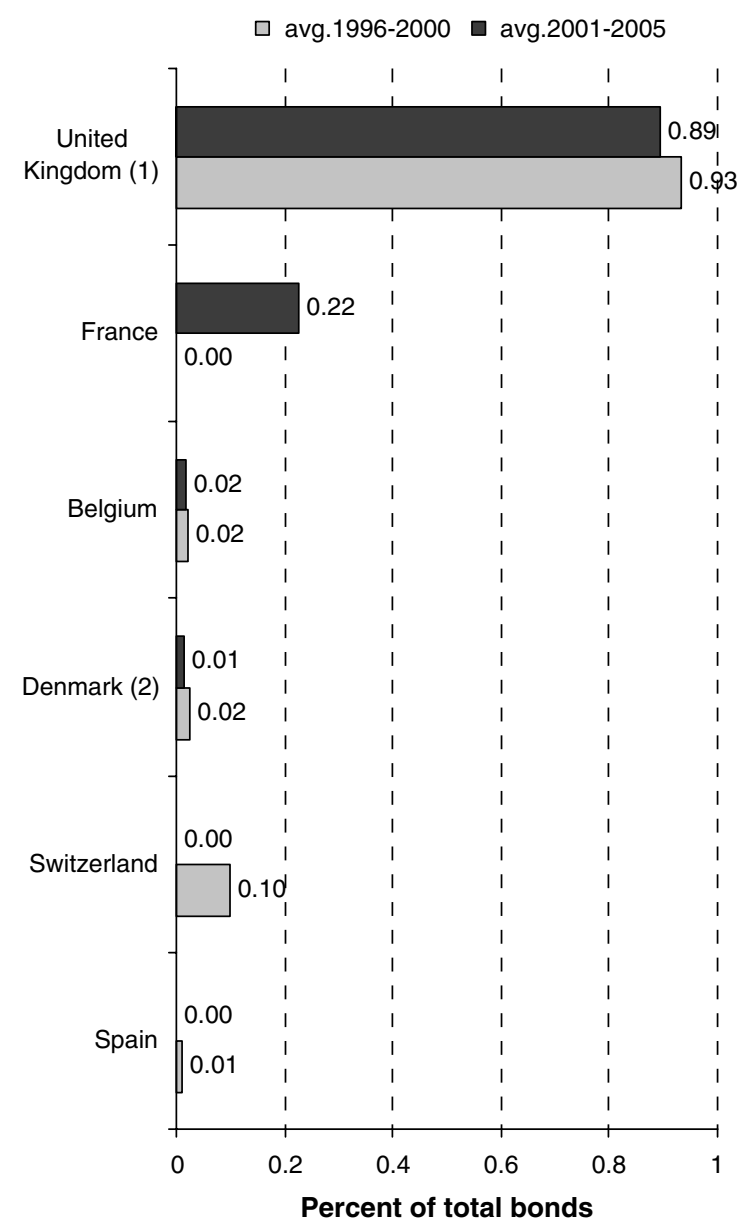

Figure 3: Government bonds outstanding, 50 years and more, averages. Government bond outstanding by residual maturity, in percent of total bonds outstanding

Note: Countries are shown in order of recent averages. Total bonds are from OECD Central Government Debt Statistics (country tables item 1.2), except for the United Kingdom (where the data are in nominal terms). Source: Replies to the OECD Working Party on Debt Management questionnaire on long-term bonds, OECD Central Government Debt Statistics, and OECD Secretariat calculations.

(1) Averages 1996-2000 are from 1999-2000 only.

(2) Perpetuals.

\section{Demand for long-dated instruments}

\section{Are pension funds and insurance companies the main investors?}

In an increasingly number of countries, pension funds and insurance companies are important investors in long-dated bonds. This trend is, 
Average term to maturity of total debt

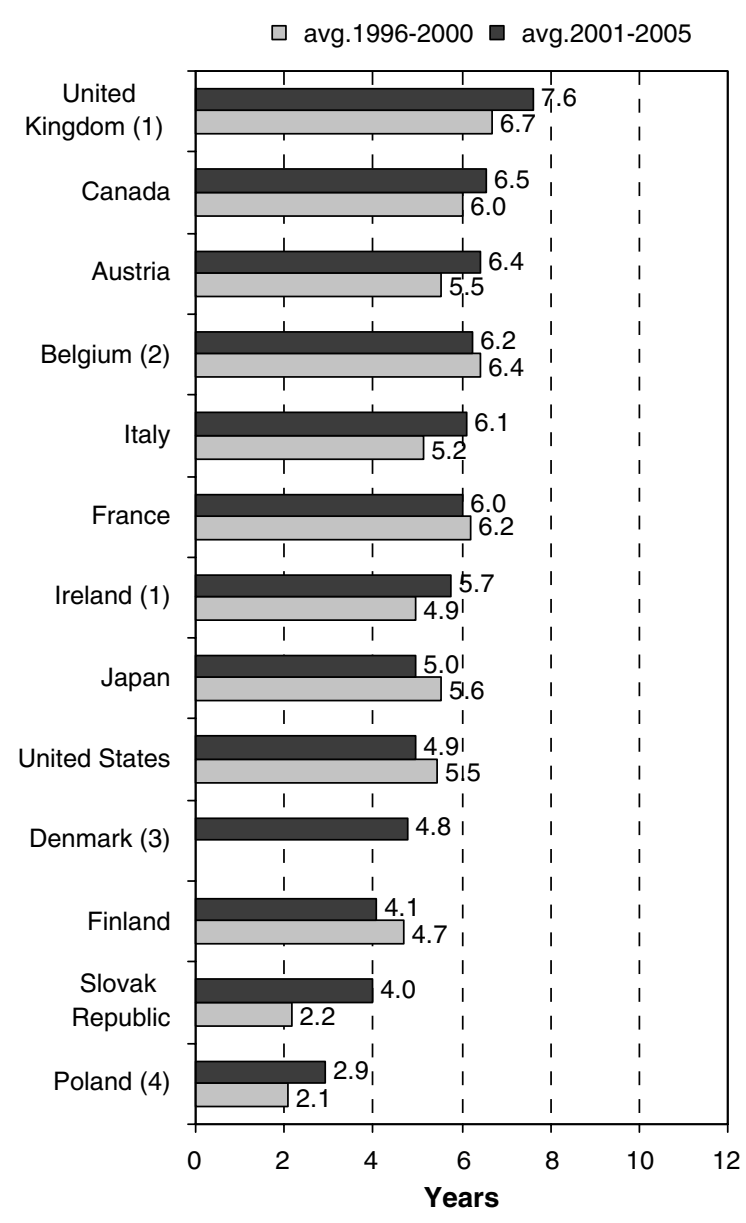

Figure 4: Government bonds outstanding, term to maturity, averages. Average term to maturity of total debt, in years Note: Countries are shown in order of recent averages. Source: Replies to the OECD Working Party on Debt Management questionnaire on long-term bonds and OECD Secretariat calculations.

(1) Average for 1996-2000 is 1999-2000 only. (2) Average for $1996-2000$ is 2000 only. (3) Average is 2003-2005 only.

(4) Average for $1996-2000$ is $1997-2000$ only.

however, not always immediately obvious from the data as it is often based on who is the buyer (by category of investor) of a new bond issue. For example, many OECD issuers use a primary dealer system; the data would then show intermediary banks as buyers, while the end investors (customers of the banks) may be pension funds. This would then constitute a problem in cases of limited transparency as to the identity of the actual end investor.
In some countries, banks or other institutional investors are important buyers or holders of longdated paper. ${ }^{4}$ The degree to which pension funds and insurance companies dominate the market depends partly on the system of retirement savings in various countries, in particular the degree of pre-funding, the design of pension systems (defined-benefit versus definedcontribution, and the degree of indexation), the maturity of pension funds, and the role of insurance companies in the market for retirement products. For example, at the end of September 2004, UK pension funds and insurance companies hold up to 64 per cent of all gilts and an even higher proportion of indexed-linked and longmaturity bonds. ${ }^{5}$ In reports on secondary market trading of Dutch government securities, pension funds and banks figure as the largest players. ${ }^{6}$ There is a growing role by the Dutch pension fund in secondary market trading of DSLs, from 18 per cent in 2003 to 25 per cent in $2005 .^{7}$ The Dutch State Treasury Agency (DSTA) attributes this development to the increasing demand for long-term fixed-income investments. In the period from January to September 2005, the share of banks in secondary market trading of Dutch government securities amounted to 40 per cent and that of insurance companies 6 per cent. $^{8}$

Although pension funds and insurance companies are important investors in long-dated paper, a significant part of demand comes also from relative value-driven accounts, such as asset managers, banks, and hedge funds. However, much of the paper taken up by relative valuedriven accounts may have ultimately gone to pension funds, requiring an increase in estimates of final allocation to pension funds and insurance companies.

\section{Motives of investors}

The investment behaviour of various categories of investors is to some degree driven by different factors. Even when they are similar, the emphasis on the different drivers may differ. As a result, they exhibit different sensitivities to changes in prices. Table 1 summarises the extent to which matching against long-dated positions and 
Table 1: Drivers of investment behaviour for different investor categories

\begin{tabular}{llllll}
\hline Driver & $\begin{array}{l}\text { Pension } \\
\text { funds }\end{array}$ & Insurers & $\begin{array}{l}\text { Banks } \\
\text { (ALM) }\end{array}$ & $\begin{array}{l}\text { Asset } \\
\text { managers }\end{array}$ & $\begin{array}{l}\text { Hedge } \\
\text { funds }\end{array}$ \\
$\begin{array}{l}\text { Swap } \\
\text { desks }\end{array}$ \\
\hline $\begin{array}{l}\text { Matching long-dated positions } \\
\text { Arbitrage (duration/convexity) }\end{array}$ & $\checkmark \checkmark \checkmark$ & $\checkmark \checkmark$ & $\checkmark$ & & $\checkmark \checkmark$ \\
\hline
\end{tabular}

Note: $\checkmark \checkmark \checkmark$ denotes very important for investment behaviour.

Source: François Marion, Agence France Trésor, 'Issuance of a 50-year French bond: Extending the frontier of the euro market,' paper presented at the 7th Annual OECD/World Bank Global Bond Market Forum, 23rd-24th May, 2005.

arbitrage are important drivers of the behaviour of different investor categories.

As noted, much of the increased demand for long-dated instruments is driven by the consequences of population ageing and stricter matching regulations governing pension funds in the Netherlands, United Kingdom, France, and other jurisdictions. Long and ultra-long paper provides a natural hedge. New international accounting standards, in particular fair-value accounting, expose more clearly the interest rate risk on the liability side of the balance sheet for entities, thereby reinforcing the need to match, for instance, pension funds' assets and long-term liabilities.

Ultra-long bonds have attractive duration characteristics. Moreover, the convexity of a 50year bond is higher than that of a 30-year bond with the same coupon. Bonds with higher convexity will outperform shorter-dated bonds when interest rates rise or fall.

\section{Influence of investment strategies}

Pension funds and insurance companies play an important role in many OECD government securities markets. The long-term nature of the liability structures of these institutional investors is an important determinant of their investment strategies. Recent changes in regulatory standards and the adoption of new international reporting standards have increased the focus on liabilitydriven investing by pension funds. ${ }^{9}$

\section{How large is the influence of liability-driven investing by pension funds?}

Indeed, regulatory changes (such as stricter funding rules and solvency requirements) and the adoption of new accounting rules (such as fairvalue reporting) for pension funds are key drivers of the shift to liability-driven investing. New regulations and accounting rules are more strongly determining investment decisions of pension funds than in the recent past.

Marking-to-market larger parts of the balance sheets of pension funds and insurance companies encourages a reduction in duration mismatches, so as to lower the volatility in their financial results. Consequently, mark-to-market accounting has two major implications: first, an increase in the demand for longer-dated bonds; and secondly, a stronger emphasis on risk management and risk budgeting by pension funds.

This, in turn, is encouraging an explicit separation between alpha and beta and more active risk-taking. What does this mean in practice? From the perspective of beta strategies, it means a shift to more low-risk indexing for large efficient asset classes, such as large capitalisation equities, but also fixed income. From the perspective of alpha strategies, it means a greater allocation to alternative assets that are uncorrelated with publicly traded securities, such as hedge funds, commodities, and private equity. Analysts have noted that fixed-income instruments can also be used as a source of alpha.

New regulations focusing on stricter funding rules and coverage ratios, such as under the new regulatory framework for pensions in the Netherlands, imply paying closer attention to the risk profile of liabilities. Liabilities are subject to two major risks: first, inflation, as many benefits are linked to cost-of-living or wage indices; and secondly, interest rate risk or duration risk, when lower interest rates increase the value of (future) 
liabilities. A common liability-driven investment strategy to protect against these two risks is immunisation (that is, duration matching) using cash bonds and/or long-term swaps. The availability of inflation-linked government bonds makes it possible to hedge both nominal and real liabilities. Ultra-long (30 years and longer) liabilities can be hedged synthetically, albeit relatively expensively, through interest rate swaps, but increasingly also by using ultra-long government bonds (both nominal and linkers).

Regulations leading to a cash flow matching of liabilities mean that pension funds' investment strategies will need to emphasise more strongly fixed income with a longer duration. The focus of pension funds and insurance companies on long-term liabilities means that they will concentrate on longer durations, implying a stronger demand for bonds. For example, in 2000 the pension fund of Boots, a British chemist, created a fully immunised portfolio, solely invested in bonds. The objective was to match the liabilities in the cheapest and most cost-effective way. Because most equity was sold before the stock market reached its bottom, Boots was very lucky. Of interest is that, in 2004, the Boots pension fund announced that it was moving 15 per cent of plan assets out of bonds into other asset classes such as stocks and real estate. According to the pension fund, the switch was executed because not all risk could be matched. ${ }^{10}$

However, there is no useful (or reliable) mechanical rule to determine, on the basis of a given amount of liabilities, the extent to which assets will be invested in (ultra-)long bonds. ${ }^{11}$ A first reason is that pension funds adopt very different mixes of alpha and beta strategies. Some pension funds argue that a significant degree of mismatching is warranted, so as to generate higher returns. Several pension funds allocate more alpha to create extra returns than others. For example, at the end of 2004 the Ontario Teacher's Pension Plan had allocated 40 per cent of its assets to real estate, commodities, and other non-traditional investments such as infrastructure projects. ${ }^{12}$ In addition, 5.4 per cent of plan assets were in hedge funds. In 2005, the pension plan of Philips Electronics shifted 60 per cent of its portfolio to liability-driven investments by exactly matching bonds to its liabilities. The average duration increased from four to 12 years. The fund's remaining 40 per cent of assets was invested in a so-called return portfolio, three quarters of which was in equity and one quarter in real estate. The objective of the return portfolio is to generate excess returns above the liabilities. PGGM (after ABP, the Netherlands' biggest fund) increased indexing and alternative-asset allocations, with around 50 per cent of its equity portfolio in indexed or enhanced index funds and an increase in the allocation to hedge funds and commodities. In 2005, PGGM's investment portfolio was allocated as follows: 30 per cent in fixed income, 47 per cent in equity, 5 per cent in private equity, 11 per cent in real estate, 5 per cent in commodities, and 2 per cent in a 'portfolio of strategies' (a new hybrid asset class with dedicated investments in beta assets with an alternative risk profile). APB's portfolio was diversified in 2005 as follows: 10.4 per cent real estate, 3.1 per cent private equity, 2.4 per cent commodities, and around 2.6 per cent in hedge funds; and the remainder as 43.2 per cent in fixed income and 38.3 per cent in equity. The CEO of APB recently outlined a new three-year investment plan that aims for an annual return of 7 per cent, with an increasingly central role for 'alternatives' and emerging-markets stocks. ${ }^{13}$

A second reason why a mechanical rule is not very useful for determining the potential demand for long-dated paper is the fact that many funds use derivatives to match their liabilities. Some analysts have argued that liability-matching swaps are to be preferred over cash bonds since swaps require very little capital to hedge the interest rate risk in the liabilities. ${ }^{14}$ It has also been noted that swaps may be more liquid than bonds. However, whether long-term swaps are more liquid than long-dated cash bonds seems debatable. Illiquid long-term interest swaps lock in funds for a very long time. This would become a problem if liabilities change significantly: for example, if unanticipated demographic changes, such as increased longevity, grow into major extra liabilities over time. Moreover, structures such as swaps are costly and complex in terms of risk 
management and administration. Nonetheless, many pension funds are expected to use swaps to comply with stricter solvency requirements. For example, both ABP and PGGM are expected to buy more liability-matching swaps to comply with the new Dutch pension regulations.

In summary, although liability-driven investing will in general encourage greater demand for long-term bonds by pension funds, it can be concluded that liability-driven investing comes in many flavours, ranging from a higher awareness of liabilities in choosing assets to increasing the duration of fixed-income portfolios so as to reduce pension funding risk or even fully immunise a pension portfolio. This, in turn, prevents the use of simple mechanical rules to predict how much additional demand for longterm bonds will flow from the adoption of this investment approach. This conclusion is in line with the outcome of consultations among investors by government issuers. For example, UKDMO reports that demand for ultra-long gilts is likely to be significant and sustainable, but views diverge on the amounts involved and the timing. Some of these assessments of potential demand for ultra-long bonds are based on estimates of the proportion of pension fund assets that could be re-allocated towards ultra-long bonds. However, views differ as to the pace and magnitude of such a re-allocation. ${ }^{15}$

\section{Are long-term rates historically low?}

Through the centuries, the real bond yield was close to 3 per cent. Long-term real interest rates in the last few years have been lower than at any other time during the past 50 years.

What is driving long-term rates and are they going to stay low? Part of the answer depends on the balance between shorter-term factors, such as monetary policy (central banks in the US and Europe have begun to raise rates), the recent financial turmoil and pressures to re-price credit risk, ${ }^{16}$ as well as long-term drivers, such as demography and globalisation, long-term expectations of inflation, the structural increase in equity market participation, and the extent to which credit spreads have fallen since the 1980s. Many analysts have singled out a global savings glut as the principal reason for exceptionally low rates. In this context, higher corporate saving and reduced investment are mentioned as offsetting factors to higher public sector deficits, leading to an ex ante global excess of saving. There is currently the highly unusual situation that the corporate sectors in both industrial countries and emerging market economies have become large net savers. ${ }^{17}$ Others prefer a financing glut (or investment gap) as the main explanation for low rates. This hypothesis argues ${ }^{18}$ that the mismatch between the global desired savings and realised investment (global nominal investment in physical assets as a share of GDP has yet to return to past levels) has led to less incremental collateralisable corporate assets. In other words, a lower stock of hard assets is now available on which to base corporate debt. On the other hand, a substantial amount of desired global savings is absorbed by governments, central banks, and financial institutions such as insurance companies and pension funds, in particular in the form of longterm debt-like instruments. The result is both a great number of buyers of long-term debt ${ }^{19}$ and a likely increase in total demand for debt instruments. At the same time, the relative supply of debt has fallen (due to lack of collateral to underpin debt, reduced issuance of debt by governments, and higher corporate savings due to a global investment gap).

\section{Long-term investing in a low interest rate environment}

Clearly, longer maturities bear significant market risk. Moreover, it is argued that in the current historically low interest rate environment, with short-term yields on their way up, investors should shorten the maturity of their bond holdings. ${ }^{20}$ In contrast, it is also noted that with a sufficiently upward-sloping yield curve, longmaturity fixed income dominates short maturities, even in the current low interest rate environment. Investing in longer-dated bonds not only adds return but also reduces risk. The case for long bonds is further strengthened when long-term liabilities are present.

In view of these considerations, what are the investment considerations of liability-driven 
investors such as pension funds? For reasons outlined above, pension funds are expected to increase their holdings of long-term bonds. For example, a few years ago the average Dutch pension fund invested 50 per cent in fixed income with an average duration of around six years. ${ }^{21}$ The Dutch State Treasury Agency (DSTA) has recently noted that Dutch pension funds are increasing their allocations of (longer-term) government paper. ${ }^{22}$ Also in the United Kingdom, long-dated government bonds are in high demand among dealers and investors, driven in large part by the need of pension funds for assets that better match their longer-term liabilities. ${ }^{23}$

Timing remains a problem for many pension funds because of today's low interest rate situation, the ongoing financial turmoil and associated liquidity and risk-pricing problems. Some analysts argue that matching against low interest rates is not a good idea. Others advocate matching and disregard the issue of timing. According to the latter view, pension funds should start with a hedging strategy, even though interest rates are low. The first step is to extend the maturity of the bond portfolio. This can be done by buying long-dated cash bonds, but also long-term interest rate swaps can be used for duration matching. However, there is still an element of timing in the sense that expected (further) rises in interest rates are likely to hold back large-scale moves. As a result, many observers expect a gradual increase in the average duration of bond holdings because large-scale moves are expensive in the present low interest rate but highly uncertain environment.

Disclaimer: The views expressed are personal ones and do not represent those of the OECD, the OECD Working Party on Public Debt Management, or its member countries.

\section{Acknowledgments}

I am indebted to my colleague Gert Wehinger for statistical assistance and to Greg Horman for helpful comments.

\section{References and Notes}

1 This market development objective can be considered an indirect objective of public debt management so as to support the direct borrowing cost and risk objectives. Debt managers attach great importance to liquid government bond markets because in the medium- or longer-term this market feature leads to lower government borrowing costs.

2 Ultra-long bonds have been issued before. For example, the UK government issued in June 1919 two ultra-long gilts: a 4 per cent Victory Bond (with a 57 -year maturity) and a 4 per cent Funding Loan (with a 71-year maturity). Taking a perspective that takes us even further back in time, we could perhaps argue that we are moving back to the steady growth, low-inflation environment of the 19th century, when perpetuals were an important part of government issuance programmes. In fact, perpetuals go back even further in time. In the 16th century, Dutch provinces and cities issued perpetual annuities, called losrenten, that were very similar to Venetian prestiti. The actual yield of these instruments is very interesting. In the 1570s, the decade before the Dutch provinces declared their independence, losrenten yielded 8.33 per cent in perpetuity.

3 The data on (ultra-)long bonds have been provided by delegates to the OECD Working Party on Debt Management. In addition, data from the OECD Central Government Debt Statistics yearbook were used in preparing the charts in this paper. In some cases, there are differences in definitions between these two data sets, as explained in the notes to the charts. These discrepancies do not affect the general trends suggested by the data.

4 It is not clear whether in some cases banks are the buyers of long-term bonds on behalf of pension funds and insurance companies. See below.

5 UKDMO (2004) 'Consultation of ultra-long gilts and gilt annuities', Press notice, 2nd December, 2004.

6 Dutch State Treasury Agency, Outlook 2006, 15th December, 2005.

7 In the same period (January to September 2005), the share of banks amounted to 40 per cent and that of insurance companies 6 per cent, as per Dutch State Treasury Agency, Outlook 2006, 15th December, 2005.

8 Banks are active traders in Dutch government securities, but they also hold large amounts of securities in portfolio on asset-liability management grounds.

9 Benoit, C. (2006) 'Financial reporting standards and public debt management', Paper prepared for the meeting of the Working Party on Debt Management, 30th-31st October, 2006, forthcoming in Hans J. Blommestein (ed.), Advances in Public Debt Management, OECD.

10 Peter, K. (2006) 'Equity are the new bonds', Euromoney, January 2006.

11 This perspective makes clear why statements about 'excess' demand for, and 'scarcity' of, long-dated paper on the basis of outstanding liabilities of pension funds and insurance companies are not very informative as guidance for issuance strategies.

$12 \mathrm{ABP}$ has started to invest in infrastructure projects through an unlisted infrastructure fund, but the fund also contemplates direct investments in this asset class. The yield is similar to that of real estate, but the long-term cash flows are stable and also offer some inflation protection.

13 Roderick Munsters is on a mission, Institutional Investor, July/August 2007.

14 Bob, L. (2005) Institutional Investor, July 2005.

15 UKDMO (2005) 'Issuance of ultra-long gilt instruments', response to consultation, 16th March, 2005.

16 Blommestein, H. J. (2007) 'Why are risks underpriced in the new financial landscape? (A global risk perspective)', Paper presented at the Abn-Amro Bank Workshop: Is risk mispriced in 
financial markets?, held at Abn-Amro Bank Headquarters in Amsterdam on 16th March, 2007.

17 For a more in-depth discussion, refer to Rudiger, A., et al. (2006) 'Factors behind low long-term interest rates', OECD Financial Market Trends, no. 91, November 2006.

18 Rajan, R. (2006) 'Is there a global shortage of fixed assets?', Remarks by Raghuram G. Rajan, Economic Counselor and Director of Research, IMF At the G-30 meetings in New York, 1st December, 2006.

19 Many financial institutions are prohibited to buy equity-like instruments (eg central banks) or financial regulations and accounting standards encourage them to invest a large part of their assets in longer-term debt-like instruments (insurance companies and pension funds).

20 The current financial turmoil is of course creating considerable uncertainty about the short-term picture for short-term rates.

21 This average fund invested 40 per cent in equity and 10 per cent in real estate, per Nederlandse pension fondsen, 2003.

22 EPN News (2006) 'Dutch bond shift begins as FTK looms', 5th June, 2006.

23 Davies, P. J. (2006) 'Demand for long UK bonds still high', Financial Times, 23rd August, 2006. 